\title{
Production of Common Colds in Human Volunteers by Influenza C Virus
}

\author{
A. C. C. JOOSTING,*† M.в., в.CH. ; B. HEAD*; M. L. BYNOE,* M.B., D.T.M.\&H., D.oBST.R.C.o.G. \\ D. A. J. TYRRELL,* M.D., F.R.C.P., M.C.PATH.
}

Brit. med. F., 1968, 4, 153-154

\begin{abstract}
Summary : Influenza $C$ virus was intranasally admini$\checkmark$ stered to volunteers; most were infected and nine developed symptoms of common cold.

Increasing titres of serum haemagglutination-inhibiting antibody and complement-fixing antibody were detected. Virus neutralizing activity in nasal secretion was not correlated with either resistance to infection or the occurrence of overt illness. Interferon was detected in the nasal secretions of some subjects.
\end{abstract}

\section{Introduction}

Influenza $\mathrm{C}$ virus was isolated many years ago from patients with respiratory disease, and has rarely been isolated since. Most of the population possess circulating antibody, presumably due to infection with this or a related agent, and rising titres are from time to time observed in patients with acute respiratory tract infections of various clinical types. Nevertheless, we know of no epidemiologically controlled study in which influenza $\mathrm{C}$ virus was shown to be causing respiratory disease. The virus might therefore have no harmful effect on man at all, and it may be found infecting patients with respiratory disease simply because it is such patients whose specimens are tested for such a virus. We therefore thought it would be of interest to determine whether human volunteers could be infected with this virus, and, if so, whether they would develop respiratory symptoms. This paper describes the results of such a study, indicating to us that influenza virus can cause a characteristic respiratory tract disease.

\section{Materials and Methods}

The volunteers were of both sexes and were cared for and studied as described elsewhere (Andrewes, 1948 ; Tyrrell, 1965). The virus was influenza $\mathrm{C} / \mathrm{J}$ ohannesburg/1/66. This virus was obtained from a swab collected from a child aged 1 month admitted to hospital with a diagnosis of pharyngitis. It was isolated by amniotic inoculation of 11-day-old chick embryos. It was passed serially four times and then transported to Salisbury, where it was passed three times at four-day intervals in organ cultures of human embryo trachea by a method modified from that of Hoorn (Tyrrell and Blamire, 1967). The fluid from the third organ culture passage was harvested ; it was not frozen, but was diluted $1 / 10$ in organ culture medium and $1 \mathrm{ml}$. was inoculated intranasally by means of a dropper. Sera were collected from volunteers the day before inoculation and two to three weeks later, and antibodies were measured by haemagglutination inhibition and complement fixation tests. The former were done both by the Takátsy method and by using $0.25-\mathrm{ml}$. volumes in W.H.O. plates with similar results ; complement fixing antigen from a prototype virus and the Johannesburg strain gave similar results.

Nasal washings were collected from volunteers two to five days after inoculation and at about the time of onset of

\footnotetext{
* Clinical Research Centre, Common Cold Research Unit, Salisbury, Wilts.
}

t Visiting Worker from the Polio Research Foundation, Johannesburg. respiratory symptoms, and were tested for virus by amniotic inoculation of 10- to 13-day-old chick embryos. The eggs were incubated at $33^{\circ} \mathrm{C}$. for three days and the virus was detected by agglutination of chicken red cells at $4^{\circ} \mathrm{C}$. Virus infectivity titrations were performed in eggs with a similar technique, tenfold dilutions and five or six eggs per dilution being used. Neutralization tests were similarly done with $50 \mathrm{EID}_{50}$ of virus/egg. Interferon was titrated with acidtreated nasal washings and the inhibition of the cytopathic effect of rhinovirus type 2 in roller tube tissue cultures of human embryonic lung fibroblasts. Nasal washings were concentrated by dialysis against polyethylene glycol 4,000 for complement fixation testing.

The virus was not neutralized by antisera against the 1233 strain Taylor and $\mathrm{C} /$ Johannesburg/654/69, but gave specific complement fixation to the same titre as a prototype strain when reacted with a human antiserum and a specific guinea-pig serum.

\section{Results}

The volunteers in the first trial were inoculated with $10^{5.7}$ egg infectious doses $\left(\mathrm{EID}_{50}\right)$, and, as can be seen from Table I, half of them developed definite symptoms and a clinical picture compatible with the diagnosis of a common cold. Virus was isolated from all six volunteers with colds and from five of six without. Three volunteers who were given fluids from uninoculated organ cultures had no symptoms. Washings which had been collected from volunteers $1,4,5,6,9$, and 10 at about the time of onset of symptoms were then pooled. 'This pool was diluted $1 / 10$ in $50 \%$ nutrient broth in Hanks's balanced salt solution and administered in a volume of $1 \mathrm{ml}$. as before to further volunteers. The virus dose administered was $10^{4.25} \mathrm{EID}_{50}$. On this occasion virus was recovered from three volunteers with colds and from three out of eight without.

TABLE I.-Results of Inoculating Volunteers with Influenza $C$ Virus

\begin{tabular}{|c|c|c|c|c|c|c|c|}
\hline \multirow{3}{*}{$\begin{array}{l}\text { No. of } \\
\text { Volun- } \\
\text { teers }\end{array}$} & \multirow{3}{*}{ Illness } & \multirow{2}{*}{\multicolumn{4}{|c|}{$\begin{array}{l}\text { Results of Virus Isolation } \\
\text { on Indicated Day after } \\
\text { Inoculation }\end{array}$}} & \multicolumn{2}{|c|}{ Antibody Titres } \\
\hline & & & & & & \multirow{2}{*}{$\begin{array}{l}\text { Haem- } \\
\text { agglutination } \\
\text { Inhibition }\end{array}$} & \multirow{2}{*}{$\begin{array}{c}\text { Complemen } \\
\text { Fixation }\end{array}$} \\
\hline & & 3 & 4 & 5 & 6 & & \\
\hline \multicolumn{8}{|c|}{ Inoculated with Organ $C$} \\
\hline 1 & Mild cold & - & + & + & - & $16 / 64$ & $10 / 10$ \\
\hline 2 & None & + & + & - & - & $16 / 16$ & -110 \\
\hline 3 & None & 0 & 0 & - & - & $128 / 128$ & $160 / 160$ \\
\hline 4 & Mild cold & - & + & + & - & $16 /-$ & $5 / 20$ \\
\hline 5 & Mild cold & + & + & + & $\overline{-}$ & $32 / 128$ & $5 / 20$ \\
\hline $\begin{array}{l}6 \\
7\end{array}$ & Mild cold & \pm & \pm & \pm & $=$ & $64 / 128$ & $80 / 80$ \\
\hline 8 & $\begin{array}{l}\text { Mild cold } \\
\text { None }\end{array}$ & $\stackrel{+}{+}$ & $\stackrel{+}{+}$ & $=$ & $=$ & $64 / 128$ & $40 / 20$ \\
\hline 9 & Mild cold & + & + & - & + & $16 / 128$ & $<5 / 40$ \\
\hline 10 & $\mathrm{No}$ & + & $\mathbf{0}$ & - & + & $-1-1$ & $40 / 40$ \\
\hline $\begin{array}{l}11 \\
12\end{array}$ & $\begin{array}{l}\text { None } \\
\text { None }\end{array}$ & $\overline{-}$ & $\stackrel{+}{+}$ & $\bar{z}$ & $\bar{z}$ & $\begin{array}{l}10 / 128 \\
32 / 32\end{array}$ & $\begin{array}{l}5 / 80 \\
<5 / 5\end{array}$ \\
\hline \multicolumn{8}{|c|}{ Inoculated with Pooled Nasal Washings } \\
\hline & None & 0 & 0 & 0 & - & $64 / 64$ & $40 / 40$ \\
\hline 17 & Mild cold & + & + & 0 & - & $32 / 128$ & $20 / 20$ \\
\hline 18 & None & 0 & 0 & ? & - & $32 / 64$ & $20 / 40$ \\
\hline $\begin{array}{l}19 \\
20\end{array}$ & $\begin{array}{l}\text { Severe cold } \\
\text { None }\end{array}$ & + & $\stackrel{+}{0}$ & $\stackrel{+}{0}$ & $=$ & $\overline{64 / 128}$ & $-10 / 20$ \\
\hline 21 & Mild cold & + & + & + & + & $32 / 128$ & $10 / 80$ \\
\hline 22 & None & + & + & + & - & $64 / 128$ & $10 / 40$ \\
\hline 23 & None & + & + & + & - & $64 / 64$ & $40 / \geqslant 320$ \\
\hline 24 & None & 0 & + & 0 & - & $\begin{array}{r}64 / 128 \\
128 / 128\end{array}$ & $10 / 40$ \\
\hline $\begin{array}{l}25 \\
26\end{array}$ & Non & - & - & - & - & & -110 \\
\hline & None & & & & & $16 / 128$ & $20 /-$ \\
\hline
\end{tabular}


Two volunteers were given $50 \%$ nutrient broth in Hanks's balanced salt solution; they did not develop colds.

Fourfold rises in titre were found by complement fixation test in four out of eight with colds and four out of 14 without. On haemagglutination inhibition test fourfold rises occurred in five subjects with colds and in two without.

The results were examined for evidence that circulating antibody was correlated with resistance to infection. Of 15 volunteers with haemagglutination-inhibiting antibody of titre more than $1: 16$ at the time of exposure 10 became infected, and of six volunteers with titres of 16 or less all were infected. Of nine volunteers with complement fixation titres over $1: 10$ six were infected, and of 10 volunteers with titres of $1: 10$ or less nine were infected.

Though the differences were small it was noted that virus infection was more frequent in those who developed colds than in those who did not, and in those who had low titres of circulating antibody than in those who had high titres.

Neutralizing activity in the nasal secretions to titres of over $1: 8$ per $100 \mu \mathrm{g}$. of protein was found in two out of six volunteers who developed colds, and in three out of six volunteers without colds. Complement fixing activity was found in the nasal washing concentrate (titre $10: 1$ ) collected four days after inoculation from one volunteer in the first trial who was not infected with the virus ; no other complement fixing activity was detected.

The illnesses observed did not suggest the diagnosis of influenza; one was graded as severe-that is, requiring bed rest-none as moderate, and eight as mild. The fever and malaise in the severe illness may have been due to cystitis, which developed as an intercurrent infection during the period of observation. The main clinical features are shown in Table II, from which it can be seen that coryza and moderate nasal discharge occurred. It may or may not be significant that mucopurulent nasal discharge and cough were not observed, and that the duration of illness was shorter than with rhinoviruses. The long incubation period of four days is distinct

TABLE II.-Clinical Features of Illness in Volunteers Inoculated with Influenza $C$ or with a Rhinovirus

\begin{tabular}{|c|c|c|c|c|}
\hline & & & $\begin{array}{l}\text { Rhinovirus } \\
\text { Type } 2\end{array}$ & $\underset{\mathrm{C}}{\text { Influenza }}$ \\
\hline 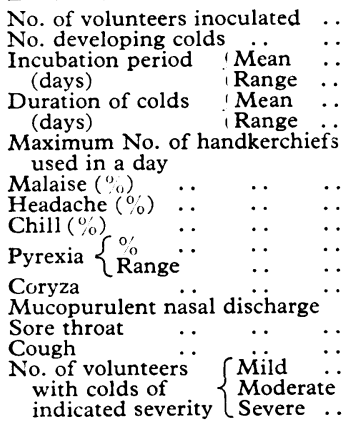 & 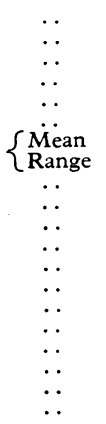 & 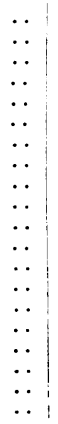 & $\begin{array}{c}213 \\
78(37 \%) \\
2 \cdot 1 \\
1-5 \\
9 \\
3-19 \\
14 \\
3-38 \\
28 \\
56 \\
28 \\
14 \\
99 \cdot 2-100 \cdot 4 \\
100 \\
83 \\
87 \\
68 \\
63(81 \%) \\
12(15 \%) \\
3(4 \%)\end{array}$ & $\begin{array}{c}23 \\
9(39 \%) \\
4 \\
3-6 \\
6 \\
5-11 \\
15 \\
5-41 \\
56 \\
56 \\
0 \\
33 \\
99 \cdot 2-102 \cdot 8 \\
100 \\
0 \\
78 \\
0 \\
8(89 \%) \\
1(11 \%)\end{array}$ \\
\hline
\end{tabular}

from that seen in influenza and rhinovirus infections, and resembles that seen in infections with avian-infectiousbronchitis-like virus infections and parainfluenza viruses (Bradburne et al., 1967 ; Reichelderfer et al., 1958).

Interferon was detected in washings from 6 out of 17 infected volunteers and in three out of four uninfected volunteers.

\section{Discussion}

These experiments seem to show that influenza $\mathrm{C}$ virus is capable of producing colds in human volunteers, but some aspects of the infection are still obscure. Virus was easily isolated from the fresh nasal washings and was found regularly on consecutive days in most infected volunteers. Excretion of virus began at least as early as the third day after inoculation, often two to three days before the onset of symptoms. Virus was still found in one volunteer four days after the cold began. In view of these findings it remains surprising that this virus has so seldom been isolated from clinical specimens. This may possibly be because inapparent infection is common, and even if it is clinically detectable it does not disturb the patient sufficiently to warrant his visiting the doctor.

Serological methods have sometimes shown rising titres in adult subjects, but these probably detect only about half the infections taking place, since rises were seen in only 8 of the 17 volunteers shown to be infected by virus isolation.

There was a tendency for resistance to infection to be correlated with circulating antibody, but it was surprising that there was no better correlation between such resistance and the presence of neutralizing activity in nasal secretion before inoculation. The one volunteer showing the presence of complement fixing antibody in the nasal secretion was the only one who was not infected in the first trial. However, the numbers are small, and even in the second trial rather a lot of interferon assays were positive in relatively few nasal washings compared with other infections studied here (A. A. Smorodintsev et al., unpublished), and this may be related to the relatively mild illness produced.

We wish to thank the volunteers for their co-operation; Miss M. D. Turnbull, S.R.N., for help with clinical observations ; and Miss N. Frost for technical assistance. We are grateful to Dr. H. G. Pereira and Dr. C. P. Bradstreet for reference sera and antigen. The work was supported in part by the World Health Organization.

\section{REFERENCES}

Andrewes, C. H. (1948). f. roy. Soc. Arts, 46, 200.

Bradburne, A. F., Bynoe, M. L., and Tyrrell, D. A. J. (1967). Brit. med. f., 3, 767.

Reichelderfer, T. E., et al. (1958). Science, 128, 779.

Tyrrell, D. A. J. (1965). Common Colds and Related Diseases. London.

Tyrrell, D. A. J., and Blamire, C. J. (1967). Brit. F. exp. Path., 48, 217.

Tyrrell, D. A. J., Bynoe, M. L., Petersen, K. B., Sutton, R. N. P., and rrell, D. A. J., Bynoe, M. L., Petersen, K. B.,
Pereira, M. S. (1959). Brit. med. F., 2, 909. 